Annals of Plant and Soil Research 23(1): 99-103 (2021)

https://doi.org/10.47815/apsr.2021.10037

\title{
Influence of varieties and spacing on growth characters of sprouting broccoli (Brassica oleracea L.)
}

\section{SANJAY KUMAR, PRADEEP KUMAR, M.L. MEENA, RAJEEV KUMAR, RANJEET RAWAT AND SHATRUNJAY YADA}

\author{
Department of Horticulture, Babasahab Bhimrao Ambedkar University, Lucknow-226025
}

Received: September, 2020; Revised accepted: November, 2020

\begin{abstract}
The investigation was undertaken at B.B.A. University, Lucknow (UP) duringrabi season of 2017-18 and 2018-19 to study theinfluence of varieties and spacing on growth characters of sprouting broccoli (Brassica oleracea L. var. italic Plenck). Four varieties viz. $V_{1}$-Pusa Broccoli KTS-1, V $V_{2}$-Palam Kanchan , $V_{3}$-Palam Vichitra, $V_{4}$-Palam Samridhi and four spacings viz.- $S_{1}-60 \times 45 \mathrm{~cm}, S_{2}-60 \times 30 \mathrm{~cm}, S_{3}-45 \times 45 \mathrm{~cm}, S_{4}-45 \times 30$ $\mathrm{cm}$ were evaluated in factorial randomized block design with three replications. The results revealed that the variety Pusa Broccoli KTS-1 showed the highest plant height $(66.7$ and $66.2 \mathrm{~cm}$ ), stem diameter (3.5 and 3.5 $\mathrm{cm})$,plant spreading $(E-W$ and $N-S)(61.3,62.5$ and 54.2, $55.3 \mathrm{~cm})$, leaves per plant (23.7 and 23.9), length of leaves $(51.1$ and $51.1 \mathrm{~cm})$ and width of leaves $(30.3$ and $30.6 \mathrm{~cm})$. Spacingof $60 \times 45 \mathrm{~cm}$ produced significantly highest values of plant height $(67.3$ and $68.4 \mathrm{~cm})$, stem diameter $(3.4$ and $3.4 \mathrm{~cm})$, leaves per plant $(24.3$ and 24.5), length of leaves (51.9 and $52.0 \mathrm{~cm}$ ) and width of leaves $(31.0$ and $31.2 \mathrm{~cm})$. The lowest values of these growth characters were recorded under spacing of $45 \times 30 \mathrm{~cm}$. The interaction effect between varietyPalamVichitraand spacing of $60 \times 45 \mathrm{cmshowed} \mathrm{significant} \mathrm{beneficial} \mathrm{effect} \mathrm{on} \mathrm{growth} \mathrm{parameters} \mathrm{viz.-}$ plant height (68.3 and $68.8 \mathrm{~cm}$ ), stem diameter $(3.5$ and $3.6 \mathrm{~cm})$, plant spreading $(E-W$ and $N-S)(64.1$ and 68.1 and 54.5 and $55.6 \mathrm{~cm})$, leaves per plant $(24.7$ and 24.9), length of leaves $(52.7$ and $52.5 \mathrm{~cm})$ and width of leaves $(31.3$ and $31.3 \mathrm{~cm})$ in sprouting broccoli.
\end{abstract}

Kewwords: Broccoli, varieties, spacing, growth characters

\section{INTRODUCTION}

Broccoli (Brassica oleraceaL. var. italica) is a member of the Brassicaceae family. Morphologically, sprouting broccoli resembles cauliflower. The plant frames a sort of head, comprising of green buds and thick beefy blossom stalks. The terminal head is fairly free, greenin shading and blossom stalks are longer than cauliflower (Thamburaj and Singh, 2013). It is utilized as plate of mixed greens, half bubbled vegetables, blended in soup with juice of different vegetables and cooked as single or blended vegetables in with potato. It is appreciated for its delectable taste, season and nutritive worth and has been accounted for to forestall disease. It is additionally favored via cardiovascular patients. Broccoli contains around $2500 \mathrm{IU}$ nutrient $\mathrm{A}, 103 \mathrm{mg}$ calcium, 78 $\mathrm{mg}$ phosphorus, $382 \mathrm{mg}$ potassium and $113 \mathrm{mg}$ nutrient $\mathrm{C}$ for every $100 \mathrm{~g}$ palatable bit. It is additionally rich in sulphoraphane which is known to have against malignancy properties. Being a cool season crop, it requires $15-20^{\circ} \mathrm{C}$ temperature for head creation. Temperature above $25^{\circ} \mathrm{C}$ isn't favorable for its development and can cause slackening and darting of heads. The head is collected alongside a couple of leaves and stem (Singh et al.2014).Varieties play a crucial role in growth and development of crop.In broccoli, very few cultivars such as Pusa KTS-1, PalamSamridhi, PalamVichitra, PalamKanchanand Punjab Broccoli-1, which are developed for very cool winter of North India.Optimum plant spacing is one of the important factors in growth parameters of crops. Therefore, present studies were aimed at promotion of high valued broccoli by identifying and standardization of different varieties and optimum plant spacing to obtain better growth characters of sprouting broccoli is important for Lucknowcondition. Keeping in view the above facts, the present investigation was planned using broccoli as test crop.

\section{MATERIALS AND METHODS}

The field experiment was conducted at BabasahebBhimraoAmbedkar University, Lucknow (UP), during rabi seasons of 2017-18 and 2018-19. The experimental site is situated at $26^{\circ} 50 \mathrm{~N}$ latitude, $80^{\circ} 52^{\prime} \mathrm{E}$ longitude and altitude 
of 111 meter above mean sea level (MSL). The area experiences rainfall from April to October with many rains from June to early September. The area receives average rainfall between 800 and $1000 \mathrm{~mm}$ with annual temperature ranging from 15 to $30^{\circ} \mathrm{C}$.Transplanting was done when the seedlings were 30 days old. The transplanting was done on $24^{\text {th }} \mathrm{Nov} .2017$ and $26^{\text {th }}$ Nov.2018in first and second year, respectively.Four varieties viz. $\mathrm{V}_{1}$ - Pusa Broccoli KTS-1, $V_{2}$-Palam Kanchan, $V_{3}$-Palam Vichitra, $\mathrm{V}_{4}$-Palam Samridhi with four spacing's viz.- $S_{1}$ $60 \times 45 \mathrm{~cm}, \mathrm{~S}_{2}-60 \times 30 \mathrm{~cm}, \mathrm{~S}_{3}-45 \times 45 \mathrm{~cm}, \mathrm{~S}_{4}-$ $45 \times 30 \mathrm{cmwereevaluated} \mathrm{in} \mathrm{factorial} \mathrm{randomized}$ block design with three replications. Recommended dose of $\mathrm{N}, \mathrm{P}_{2} \mathrm{O}_{5}$ and $\mathrm{K}_{2} \mathrm{O}$ was supplied through urea, single superphosphate and muriate of potash, respectively. Appropriate management practices were adopted to raise the crop.The observations were recorded on growth parameters viz.-Plant height, stem diameter, plant spreading (E-W direction), plant spreading (N-S direction), leaves per plant, length and, width of leaves and dry weight of plant.All the parameters were collected from randomly selected plants of each treatment. Observations on vegetative parameters were recorded at proper stage and statistically analyzed.

\section{RESULTS AND DISCUSSION}

\section{Influence of varieties}

Variety Pusa Broccoli KTS-1 recorded (66.7 and $67.2 \mathrm{~cm}$, respectively) the highest plant height during first and second year, respectively, which was followed by variety PalamKanchan $(66.7$ and $67.1 \mathrm{~cm})$ in both years. While minimum plant height were obtained in variety Palam Vichitra $(66.0$ and $66.0 \mathrm{~cm})$.

Table 1: Influence of varieties and spacing's on growth characters of sprouting broccoli

\begin{tabular}{|c|c|c|c|c|c|c|c|c|}
\hline \multirow[t]{2}{*}{ Treatment } & \multicolumn{2}{|c|}{ Plant height $(\mathrm{cm})$} & \multicolumn{2}{|c|}{$\begin{array}{l}\text { Stem diameter } \\
(\mathrm{cm})\end{array}$} & \multicolumn{2}{|c|}{$\begin{array}{l}\text { Plant spreading (E- } \\
\text { W) direction }(\mathrm{cm})\end{array}$} & \multicolumn{2}{|c|}{$\begin{array}{c}\text { Plant spreading }(\mathrm{N}-\mathrm{S}) \\
\text { direction }(\mathrm{cm})\end{array}$} \\
\hline & 2017-18 & $2018-19$ & $2017-18$ & $2018-19$ & $2017-18$ & $2018-19$ & $2017-18$ & $2018-19$ \\
\hline \multicolumn{9}{|l|}{ Varieties $(\mathrm{V})$} \\
\hline $\mathrm{V}_{1}$ (Pusa Broccoli KTS-1) & 66.7 & 67.2 & 3.5 & 3.5 & 61.3 & 62.5 & 54.2 & 55.3 \\
\hline$V_{2}$ (PalamKanchan) & 66.7 & 67.1 & 3.3 & 3.4 & 61.3 & 61.9 & 54.0 & 54.5 \\
\hline$V_{3}$ (PalanVichitra) & 66.0 & 66.0 & 3.1 & 3.1 & 58.4 & 56.9 & 50.3 & 49.4 \\
\hline $\mathrm{V}_{4}$ (PalamSamridhi) & 66.5 & 66.6 & 3.1 & 3.2 & 58.6 & 57.0 & 50.4 & 49.4 \\
\hline $\mathrm{CD}(\mathrm{P}=0.05)$ & 0.38 & 0.41 & 0.34 & 0.33 & 1.25 & 1.33 & 0.41 & 0.49 \\
\hline \multicolumn{9}{|l|}{ Spacing $(\mathrm{S})$} \\
\hline $\mathrm{S}_{1}(60 \times 45 \mathrm{~cm})$ & 67.3 & 68.4 & 3.4 & 3.4 & 62.5 & 64.0 & 52.8 & 53.2 \\
\hline $\mathrm{S}_{2}(60 \times 30 \mathrm{~cm})$ & 67.3 & 67.4 & 3.2 & 3.3 & 60.4 & 60.5 & 52.4 & 52.8 \\
\hline $\mathrm{S}_{3}(45 \times 45 \mathrm{~cm})$ & 65.8 & 65.9 & 3.2 & 3.2 & 59.4 & 59.3 & 52.0 & 52.0 \\
\hline $\mathrm{S}_{4}(45 \times 30 \mathrm{~cm})$ & 64.6 & 65.1 & 3.2 & 3.2 & 57.3 & 54.5 & 51.7 & 50.7 \\
\hline $\mathrm{CD}(\mathrm{P}=0.05)$ & 0.38 & 0.41 & 0.34 & 0.33 & 1.25 & 1.73 & 0.41 & 0.49 \\
\hline \multicolumn{9}{|l|}{ Interaction (VxS) } \\
\hline $\mathrm{V}_{1} \mathrm{~S}_{1}$ & 68.3 & 68.8 & 3.5 & 3.6 & 64.1 & 68.1 & 54.5 & 55.6 \\
\hline$V_{1} S_{2}$ & 67.8 & 68.1 & 3.5 & 3.5 & 63.8 & 64.1 & 54.2 & 55.4 \\
\hline $\mathrm{V}_{1} \mathrm{~S}_{3}$ & 66.2 & 66.3 & 3.4 & 3.5 & 61.3 & 63.1 & 54.2 & 55.3 \\
\hline$V_{1} S_{4}$ & 64.9 & 65.5 & 3.4 & 3.4 & 56.3 & 54.6 & 54.0 & 55.0 \\
\hline $\mathrm{V}_{2} \mathrm{~S}_{1}$ & 67.4 & 68.7 & 3.5 & 3.5 & 62.0 & 63.9 & 54.4 & 55.3 \\
\hline $\mathrm{V}_{2} \mathrm{~S}_{2}$ & 67.6 & 67.6 & 3.3 & 3.4 & 61.2 & 63.6 & 54.1 & 50.0 \\
\hline $\mathrm{V}_{2} \mathrm{~S}_{3}$ & 65.9 & 65.2 & 3.3 & 3.3 & 61.0 & 62.4 & 54.0 & 54.2 \\
\hline $\mathrm{V}_{2} \mathrm{~S}_{4}$ & 65.1 & 65.2 & 3.2 & 3.3 & 60.9 & 57.5 & 53.4 & 51.6 \\
\hline $\mathrm{V}_{3} \mathrm{~S}_{1}$ & 67.5 & 68.2 & 3.2 & 3.2 & 63.6 & 63.6 & 51.0 & 50.4 \\
\hline$V_{3} S_{2}$ & 66.7 & 67.4 & 3.1 & 3.1 & 57.2 & 57.3 & 50.8 & 49.9 \\
\hline $\mathrm{V}_{3} \mathrm{~S}_{3}$ & 65.6 & 65.4 & 3.1 & 3.1 & 56.9 & 55.8 & 49.9 & 48.8 \\
\hline$V_{3} S_{4}$ & 64.3 & 64.4 & 3.1 & 3.1 & 55.9 & 51.0 & 48.5 & 48.4 \\
\hline $\mathrm{V}_{4} \mathrm{~S}_{1}$ & 65.5 & 66.8 & 3.2 & 3.2 & 60.3 & 60.3 & 51.4 & 50.4 \\
\hline$V_{4} S_{2}$ & 67.0 & 66.6 & 3.1 & 3.1 & 59.4 & 57.2 & 50.6 & 49.9 \\
\hline $\mathrm{V}_{4} \mathrm{~S}_{3}$ & 65.4 & 65.3 & 3.1 & 3.1 & 58.3 & 55.8 & 49.9 & 49.6 \\
\hline $\mathrm{V}_{4} \mathrm{~S}_{4}$ & 64.6 & 65.1 & 3.1 & 3.1 & 56.3 & 54.9 & 49.5 & 47.7 \\
\hline $\mathrm{CD}(\mathrm{P}=0.05)$ & 0.76 & 0.82 & 0.68 & 0.66 & 2.50 & 2.46 & 0.82 & 0.98 \\
\hline
\end{tabular}


Maximum stem diameter (3.5and $3.5 \mathrm{~cm}$ ), plant canopy spreading (E-W direction) (61.3 and $62.5 \mathrm{~cm}$ ) and plant canopy spreading (N-S direction), (54.27 and $55.38 \mathrm{~cm}$,) were recorded in variety Pusa Broccoli KTS-1 during individual year, which was consequently pursued by variety Palam Kanchan, whereas, minimum values were recorded in PalamVichitra. Variety Pusa Broccoli KTS-1 recorded maximum number of leaves per plant (23.7 and 23.9), length (51.1 and $51.1 \mathrm{~cm}$ ) and width of leaves (30.3 and 30.6 $\mathrm{cm})$ during first and second year, respectively.Minimum values were recorded in variety PalamVichitra. These results are in close conformity with the results of Bhangre et al.(2011). Pusa KTS-1 recorded essentially most elevated qualities for growth parameters. Varieties Palam Kanchan recorded the highest dry weight of plant pursued by PalamVichitra. Thus, there appeared to be very wide differences among these four varieties with respect to growth characters. This may be attributed to variation in the genetic variability among the varieties against growth characters as well as due to changing in the agroclimatic condition. These results are close conformity with the finding of Thakur et al.(2016) and Ngullie and Biswas (2014).

\section{Influence of spacing}

Table 1\&2 revealed that the growth parameters were significantly affected by different spacings. Plant spacing $(60 \times 45 \mathrm{~cm}) \mathrm{had}$ recorded maximum plant height(67.3and $68.4 \mathrm{~cm}$ ) during first and second year, respectively followed by spacing of $60 \times 30 \mathrm{~cm}(67.3$ and $67.4 \mathrm{~cm}$, ) whereas, minimum values were obtained in spacing of $45 \times 30 \mathrm{~cm}$ $(64.6$ and $65.1 \mathrm{~cm})$. .At the end of experiment, maximum stem diameter $(3.4$ and $3.4 \mathrm{~cm})$, plant canopy spreading (E-W direction), (62.5 and $64.0 \mathrm{~cm})$ and plant canopy spreading (N-S direction), (52.8and $53.2 \mathrm{~cm}$ ) were recorded in spacing of $60 \times 45 \mathrm{~cm}$ during individual year, respectively which was followed by spacing of $45 \times 30 \mathrm{~cm}$. Minimum values were recorded in spacing of $45 \times 30 \mathrm{~cm}$. These results are in close conformity with the findings of Solunkeet
al.(2011).Spacing of $60 \times 45 \mathrm{~cm}$ recorded maximum number of leaves per plant (24.3 and $24.5)$, length of leaves $(51.9$ and $52.0 \mathrm{~cm})$ and width of leaves $(31.0$ and $31.2 \mathrm{~cm}$ ) during first and second year, respectively, while minimum values were recorded in spacing of $45 \times 30 \mathrm{~cm}$. These findings are in accordance with the findings of Munro et al. (2007), Kumar et al. (2007), (Saikiaa and Sanchita Brahma (2010) and Bhangreet al.(2001) in broccoli.Plant spacing $(60 \times 45 \mathrm{~cm})$ had recorded maximum dry weight of plant (164.8 and169.2g) during first and second year, respectively. The higher values of growth parameters at higher plant spacing might mainly due to increased intra-row plant competition for light, moisture, nutrients and other environmental resources under this treatment. Similar results were reported byAgarkaret al. (2010), Kumar et al. (2007) and Vinodsutaret al. (2017).

\section{Interaction}

Table- 1\&2 showed that the growth parameters were significantly influenced by interaction between varieties and spacing's. The maximum plant height was recorded under $V_{1} S_{1}$ treatment $(68.3$ and $68.8 \mathrm{~cm})$ during first and second year, respectively. Significantly maximum stem diameter during first and second year ( 3.5 and $3.4 \mathrm{~cm}$, respectively), plant canopy spreading (E-W and N-S), (64.1, 68.1 and 54.5, $55.6 \mathrm{~cm}$,). was recorded under $\mathrm{V}_{1} \times \mathrm{S}_{1}$ treatment. Interaction $\mathrm{V}_{1} \mathrm{~S}_{1}$ produced maximum leaves per plant (24.7 and 24.9), length of leaves (52.7and $52.5 \mathrm{~cm})$ and width of leaves $(31.3$ and $31.3 \mathrm{~cm}$,), followed by interaction $V_{2} S_{1}$. Similar results were also observed by (Saikiaand Sanchita Brahma.2010). The minimum leaves per plant, length of leaves and width of leaves was observed under $\mathrm{V}_{3} \mathrm{~S}_{4}$. Maximum dry weight of plant was observed in $\mathrm{V}_{2} \mathrm{~S}_{4}$ (201.3 and 206.1g) during first and second year, respectively followed by $\mathrm{V}_{2} \mathrm{~S}_{3}$ (194.3and 204.3g) during first and second year, respectively, whereas, minimum dry weight of plant was obtained in $\mathrm{V}_{1} \mathrm{~S}_{1}$. These results are in close conformitywith the resulls of Bhangreet al. (2011). 
Table 2: Influence of varieties and spacing on growth characters of sprouting broccoli

\begin{tabular}{|c|c|c|c|c|c|c|c|c|}
\hline \multirow[t]{2}{*}{ Treatment } & \multicolumn{2}{|c|}{$\begin{array}{c}\text { Number of leaves } \\
\text { per plant }\end{array}$} & \multicolumn{2}{|c|}{$\begin{array}{c}\text { Length of leaves } \\
(\mathrm{cm})\end{array}$} & \multicolumn{2}{|c|}{$\begin{array}{l}\text { Width of leaves } \\
(\mathrm{cm})\end{array}$} & \multicolumn{2}{|c|}{\begin{tabular}{|c|} 
Dry weight of plant \\
$(\mathrm{g})$
\end{tabular}} \\
\hline & 2017-18 & $2018-19$ & 2017-18 & $2018-19$ & 2017-18 & $2018-19$ & 2017-18 & $2018-19$ \\
\hline \multicolumn{9}{|l|}{ Varieties $(\mathrm{V})$} \\
\hline $\mathrm{V}_{1}$ (Pusa Broccoli KTS-1) & 23.7 & 23.9 & 51.1 & 51.1 & 30.3 & 30.6 & 109.1 & 115.6 \\
\hline$V_{2}$ (PalamKanchan) & 23.6 & 23.7 & 50.8 & 50.9 & 29.8 & 30.1 & 190.3 & 198.0 \\
\hline$V_{3}$ (PalanVichitra) & 23.2 & 23.2 & 49.1 & 49.0 & 29.4 & 29.6 & 176.0 & 179.5 \\
\hline $\mathrm{V}_{4}$ (PalamSamridhi) & 23.5 & 23.7 & 50.6 & 50.7 & 29.8 & 30.0 & 114.8 & 121.7 \\
\hline $\mathrm{CD}(\mathrm{P}=0.05)$ & 0.37 & 0.43 & 0.31 & 0.38 & 1.01 & 0.90 & 5.17 & 9.91 \\
\hline \multicolumn{9}{|l|}{ Spacing (S) } \\
\hline $\mathrm{S}_{1}(60 \times 45 \mathrm{~cm})$ & 24.3 & 24.5 & 51.9 & 52.0 & 31.0 & 31.2 & 133.4 & 137.8 \\
\hline $\mathrm{S}_{2}(60 \times 30 \mathrm{~cm})$ & 24.0 & 24.0 & 50.8 & 50.9 & 30.5 & 30.8 & 143.9 & 148.5 \\
\hline $\mathrm{S}_{3}(45 \times 45 \mathrm{~cm})$ & 23.1 & 23.2 & 50.2 & 50.2 & 29.4 & 29.8 & 150.8 & 159.3 \\
\hline $\mathrm{S}_{4}(45 \times 30 \mathrm{~cm})$ & 22.8 & 22.8 & 48.7 & 48.6 & 28.6 & 28.5 & 164.8 & 169.2 \\
\hline$C D(P=0.05)$ & 0.37 & 0.43 & 0.31 & 0.38 & 1.01 & 0.90 & 5.17 & 9.91 \\
\hline \multicolumn{9}{|l|}{ Interaction (VxS) } \\
\hline $\mathrm{V}_{1} \mathrm{~S}_{1}$ & 24.7 & 24.9 & 52.7 & 52.5 & 31.3 & 31.3 & 99.4 & 101.7 \\
\hline $\mathrm{V}_{1} \mathrm{~S}_{2}$ & 24.2 & 24.3 & 51.4 & 51.9 & 30.7 & 31.1 & 107.7 & 110.3 \\
\hline $\mathrm{V}_{1} \mathrm{~S}_{3}$ & 23.1 & 23.4 & 51.0 & 50.7 & 30.0 & 30.4 & 110.9 & 120.1 \\
\hline $\mathrm{V}_{1} \mathrm{~S}_{4}$ & 23.0 & 23.0 & 49.3 & 49.3 & 29.1 & 29.8 & 119.3 & 130.3 \\
\hline$V_{2} S_{1}$ & 24.5 & 24.7 & 52.4 & 52.3 & 31.1 & 31.2 & 176.4 & 184.7 \\
\hline $\mathrm{V}_{2} \mathrm{~S}_{2}$ & 24.1 & 24.2 & 51.1 & 51.4 & 30.5 & 30.8 & 189.3 & 196.8 \\
\hline $\mathrm{V}_{2} \mathrm{~S}_{3}$ & 23.0 & 23.1 & 57.0 & 50.8 & 29.3 & 29.7 & 194.3 & 204.3 \\
\hline $\mathrm{V}_{2} \mathrm{~S}_{4}$ & 23.0 & 22.9 & 48.8 & 49.0 & 29.1 & 28.8 & 201.3 & 206.1 \\
\hline$V_{3} S_{1}$ & 23.9 & 24.0 & 50.4 & 51.0 & 30.4 & 31.0 & 156.3 & 162.3 \\
\hline $\mathrm{V}_{3} \mathrm{~S}_{2}$ & 23.5 & 23.4 & 49.8 & 49.0 & 30.0 & 30.4 & 174.1 & 175.3 \\
\hline $\mathrm{V}_{3} \mathrm{~S}_{3}$ & 23.3 & 23.1 & 48.3 & 48.7 & 29.4 & 29.8 & 183.2 & 188.4 \\
\hline $\mathrm{V}_{3} \mathrm{~S}_{4}$ & 22.1 & 22.4 & 47.7 & 47.3 & 28.0 & 27.1 & 190.2 & 192.1 \\
\hline $\mathrm{V}_{4} \mathrm{~S}_{1}$ & 24.1 & 24.4 & 52.1 & 52.2 & 31.1 & 31.1 & 101.3 & 102.3 \\
\hline $\mathrm{V}_{4} \mathrm{~S}_{2}$ & 24.0 & 24.1 & 51.0 & 51.3 & 30.8 & 30.9 & 104.5 & 111.7 \\
\hline $\mathrm{V}_{4} \mathrm{~S}_{3}$ & 23.0 & 23.9 & 50.4 & 50.7 & 29.0 & 29.4 & 114.8 & 124.3 \\
\hline $\mathrm{V}_{4} \mathrm{~S}_{4}$ & 22.9 & 23.0 & 49.1 & 48.8 & 28.4 & 28.4 & 138.4 & 148.5 \\
\hline $\mathrm{CD}(\mathrm{P}=0.05)$ & 0.74 & 0.86 & 0.62 & 0.76 & 2.02 & 1.80 & 10.34 & 19.82 \\
\hline
\end{tabular}

It may be concluded from the results that the varieties and spacing's showed significant variation among the different growth parameters. Generally, the wider plant spacing performed better for broccoli. Thus, variety Pusa Broccoli

\section{REFERENCES}

Agarkar, U.R., Dadmal, K.D., Nikas, N.S. and Piwlatkar, G.K. (2010) Effect of nitrogen levels and spacing on growth and yield of broccoli (Brassica oleracea var. italica L.). Green Farming 1(5): 477 -479

Bhangre, K.K., Sonawane, P.C. and Warade, S.D. (2011) Effect of different varieties and spacing on growth and yield parameters of broccoli (Brassica oleraceaL. var. ItalicaPlenck) under Pune
KTS-1 and spacing of $60 \times 45 \mathrm{~cm}$ and their interaction significantly showed the maximum plant height, stem diameter, plant canopy spreading, leaves per plant, length of leaves and width of leaves.
conditions.Asian Journal of Horticultures 80(1): 52-56.

Bhangre, K.K.,Sonawane, P.C. and Warade, S. D. (2001) Effect of different varieties and spacing on growth and yield parameters of broccoli (Brassica oleraceavar.italica) under Pune conditions, Asian Journal of Horticulture 6(1):74-76.

Kumar, N., Praskash, V. and Srivastva, A.K.(2007) Effect of transplanting dates and geometries on broccoli (Brassica 
oleraceavar. italica) under mid hill conditions of North-West Himalaya.Indian Journal of Agricultural sciences 77(7):448-450.

Munro, D.C., Mackay, D. C. and Cutcliffe, J. A. (2007) Relation of nutrient content of broccoli andbrussels sprouts leaves to maturity and fertilization with $\mathrm{N}, \mathrm{P}$ and $\mathrm{K}$ fertilizer. Canada Journal of Plant Sciences 58:385-94.

Ngullie, R. and Biswas, P.K. (2014) Performance of different varieties of broccoli under rainfed mid-hill conditions of Mokokchung district of Nagaland. International Journal of Farm Science 4(2): 76-79.

SaikiaPhookan, D.B. and Sanchita Brahma (2010)Effect of time of lanting and planting densities on growth, yield and economic production of broccoli (Brassica oleracea var. italica) cv. Pusa Broccoli KTS-1.Journal of Hill Agriculture 1(2): 135-139.

Singh, R., Kumar, S. and Kumar, S. (2014) Performance and preference of broccoli varieties grown under low hill conditions of Himachal Pradesh. Indian Research Journal of Extension Education 14(1): 112-114.

Solunke, B.G., Wagh, A.P., Dod, V.N. and Nagre, P.K. (2011) Effect of dates of planting and spacing on growth and yield of broccoli. Asian Journal of Horticulture 6: 294-296.

Thakur, R., Kushwah, S.S., Sharma, R.K. and Singh, O.P. (2016)Growth and yield of sprouting broccoli (Brassica oleraceaL. var. italica) varieties under open field and naturally ventilated polyhouse condition. The Bioscan 11(4): 2323-2326.

Thamburaj, S. and Singh, N. (2013) Textbook of Vegetables, Tubercrops and Spices.Indian Council of Agricultural Research, New Delhi (India).p. 136.

Vinodsutar, Aravindakshan, K. and Bola, P.K. (2017) Effect of different varieties andspacing on growth, yield and quality ofbroccoli (Brassica oleraceavar. italica) cultivar. Green head.Chemical science review and letters 6(21): 209-212. 